\title{
Nursery function of tropical back-reef systems
}

\author{
Aaron J. Adams ${ }^{1}$, Craig P. Dahlgren ${ }^{2, *}$, G. Todd Kellison ${ }^{3,9}$, Matthew S. Kendall ${ }^{4}$, \\ Craig A. Layman ${ }^{5}$, Janet A. Ley ${ }^{6}$, Ivan Nagelkerken ${ }^{7}$, Joseph E. Serafy ${ }^{8}$ \\ ${ }^{1}$ Mote Marine Laboratoy, Charlotte Harbor Field Station, PO Box 2197, Pineland, Florida 33945, USA \\ ${ }^{2}$ Perry Institute for Marine Science, 100 N US Highway 1, Suite 202, Jupiter, Florida 33477, USA \\ ${ }^{3}$ Biscayne National Park, 9700 SW 328th Street, Homestead, Florida 33033, USA \\ ${ }^{4}$ NOAA Biogeography Team, 1305 East West Highway, Silver Spring, Maryland 20910, USA \\ ${ }^{5}$ Department of Ecology and Evolutionary Biology, Yale University, New Haven, Connecticut 06520-8106, USA \\ ${ }^{6}$ Australian Maritime College, PO Box 21, Beauty Point, Tasmania 7270, Australia \\ ${ }^{7}$ Department of Animal Ecology and Ecophysiology, Institute for Water and Wetland Research, Radboud University \\ Nijmegen, Toernooiveld 1, 6525 ED, Nijmegen, The Netherlands \\ ${ }^{8}$ National Marine Fisheries Service, Southeast Fisheries Science Center, 75 Virginia Beach Drive, Miami, Florida 33149, USA \\ ${ }^{9}$ Present address: National Marine Fisheries Service, Southeast Fisheries Science Center, 75 Virginia Beach Drive, Miami, \\ Florida 33149, USA
}

\begin{abstract}
Similar to nearshore systems in temperate latitudes, the nursery paradigm for tropical back-reef systems is that they provide a habitat for juveniles of species that subsequently make ontogenetic shifts to adult populations on coral reefs (we refer to this as the nursery function of back-reef systems). Nevertheless, we lack a full understanding of the importance of the nursery function of back-reef systems to the maintenance of coral reef fishes and invertebrate populations; the few studies that have examined the nursery function of multiple habitats indicate that the relationship between juvenile production in back-reef habitats and their subsequent contribution to adult populations on reefs remain poorly understood. In this synopsis we (1) synthesize current knowledge of life history, ecological and habitat influences on juvenile distribution patterns and nursery function within back-reef systems; (2) outline a research strategy for assessing the nursery function of various habitat types in back-reef systems; and (3) discuss management recommendations, particularly in regard to how improved knowledge of the nursery function of back-reef systems can be used in fisheries and ecosystem management, including habitat conservation and restoration decisions. The research strategy builds on research recommendations for assessing the nursery function of temperate habitats and includes 4 levels of research: (1) building conceptual models to guide research and management; (2) identifying juvenile habitat use patterns; (3) measuring connectivity of juvenile and adult populations between habitats; and (4) examining ecological processes that may influence patterns assessed in Level 2 and Level 3 research. Research and modeling output from Levels 1 to 4 will provide an improved ecological understanding of the degree and importance of interconnections between coral reef and adjacent back-reef systems, and will provide information to managers that will facilitate wise decisions pertaining to habitat conservation, habitat restoration, and ecosystembased management, and the maintenance of sustainable fisheries.
\end{abstract}

KEY WORDS: Back-reef systems $\cdot$ Nursery $\cdot$ Nearshore habitats $\cdot$ Coral reef $\cdot$ Seagrass $\cdot$ Mangrove

\section{INTRODUCTION}

Many ecologically and economically important marine species have life histories in which juvenile stages use different habitats than adults. Understanding the ontogenetic habitat use patterns of these spe- cies and the value of different juvenile habitats for supporting adult populations is critical for effective management and conservation. Hereafter, we refer to the contribution value of different habitats as their nursery function, defined as the growth and survival of juvenile fishes and invertebrates followed by a successful onto- 
genetic habitat shift into their adult habitat. All habitats that result in a contribution of individuals to the adult population have a nursery function including, but not limited to, nursery habitats, which make a greater than average contribution to adult populations on a per unit area basis (Beck et al. 2001), and effective juvenile habitats, which make a greater than average total contribution to adult populations (Dahlgren et al. 2006).

The importance of habitat loss and degradation as causes of fish population declines is becoming increasingly apparent (Turner et al. 1999, Jones et al. 2004). Roughly $50 \%$ of the growing world population lives within $100 \mathrm{~km}$ of the coastline (Coen et al. 1997). Global population projections indicate that by the year $2025,75 \%$ of the world's population may reside in coastal areas (Hinrichsen 1998). In the United States, coastal areas comprise approximately $17 \%$ of the total land area, but $25 \%$ of coastal areas are expected to be developed by 2025 (Beach 2002), with more than $50 \%$ of the nation's population living in coastal areas (ORCA 2004: available at http://spo.nos.noaa.gov/ projects/population/population.html). As coastal human populations worldwide continue to increase, back-reef systems are likely to be increasingly stressed due to factors such as habitat loss, habitat degradation, and overfishing (Hughes 1994, Lapointe et al. 1994). Therefore, there is an exigent need to determine the ecological importance of back-reef systems so that appropriate management and conservation actions can be taken.

Recently, there have been several reviews of the nursery value of estuarine and marine habitats, and of ecological processes that influence juvenile production and nursery value (e.g. Heck et al. 1997, 2003, Beck et al. 2001, 2003, Gillanders et al. 2003, Sheridan \& Hays 2003, Stoner 2003), with examples primarily from temperate systems. Thus, the nursery function of tropical nearshore habitats remains poorly understood (e.g. Sheridan \& Hays 2003, Halpern 2004, Mumby et al. 2004) relative to temperate latitudes.

In tropical systems, adults of many economically and ecologically important species live in association with coral reefs, usually between the reef crest and deeper areas of the fore-reef slope. Nearshore environments between the coral reef and shore in the tropics include an interconnected mosaic of diverse habitat types, such as mangroves, seagrass beds, patch reefs, and various hard-bottom and soft-substrate habitats. The use of traditional terms to describe these habitats has in many cases led to confusion. For example, a lagoon can be a seagrass-dominated area adjacent to a bankbarrier reef on a small $(<1 \mathrm{~km}$ ) (Adams \& Ebersole 2002) or large (tens of $\mathrm{km}$ ) scale (Sedberry \& Carter 1993), an enclosed lagoon connected through a narrow opening (Nagelkerken et al. 2000b, Adams \& Tobias
1999), or estuaries of different salinity regimes (Austin 1971). Thus, we use the term 'back-reef system' to incorporate all habitats bound by the leeward side of the reef crest (i.e. the traditional back-reef zone) and the mean high-tide line along the shore (Dahlgren \& Marr 2004). The back-reef system is inclusive of habitats along the shoreward margin of coral reefs, within the lagoon, along the shoreline, and within estuarine, tidal creek and wetland areas along the coast.

The back-reef system often harbors a great biological diversity and high abundances of many species, particularly as juveniles. Many habitat types are often found within close proximity to each other, allowing many species to make multiple ontogenetic habitat shifts (e.g. Eggleston 1995, Dahlgren \& Eggleston 2001) or use several different habitat types within the back-reef system (e.g. as foraging areas and shelter) during the same life stage (e.g. Serafy et al. 2003). Thus, complex interactions can arise among species and habitats. Such complexity makes it difficult to evaluate the nursery function of different habitat types within back-reef systems.

Although the framework for assessing the nursery function of habitats proposed by Beck et al. (2001, 2003) has been applied primarily in temperate systems, it may be adapted for use in assessments of the nursery function of back-reef systems. The paradigm for backreef systems is that they provide a habitat for juveniles of species that subsequently make ontogenetic shifts to adult populations on coral reefs. In some cases, coral reef fish populations are supplemented by individuals from juvenile habitats in back-reef systems (Chittaro et al. 2004), and we may also infer from other studies that this process occurs (e.g. Nagelkerken et al. 2000b,c, 2002, Ley \& McIvor 2002, Dorenbosch et al. 2004a, Halpern 2004, Mumby et al. 2004). Nevertheless, the assumption that habitats within back-reef systems are important nursery habitats that make large contributions to adult populations is largely untested. Our understanding of the importance of the nursery function of back-reef systems to the maintenance of coral reef fish populations is far from complete, and even less is known for most tropical invertebrate populations. This review summarizes the state of knowledge of the nursery function of back-reef systems, and suggests a framework for further elucidating this important aspect of coral reef ecology.

\section{FACTORS UNDERLYING A NURSERY FUNCTION}

Following the framework presented by Beck et al. (2001), the nursery function of a habitat type is the result of a combination of 4 factors regarding juveniles of the species: (1) density, (2) growth, (3) survival, and 
(4) movement to adult habitats (i.e. connectivity). In most instances, the nursery function of habitat types has been inferred rather than directly demonstrated, typically from studies addressing only 1 or 2 of Factors 1 to 3 for a single species (Beck et al. 2001). Additional information regarding connectivity between juvenile production and adult populations continues to be lacking for nearly all back-reef systems.

In back-reef systems, studies of the relative growth or mortality of juvenile fishes or invertebrates in different habitats provide information on the ecological processes that influence the nursery function of different habitats. Mortality of fishes at settlement stage or undergoing post-settlement transition can be extremely high, as recently estimated for Naso unicornis in a Pacific back-reef lagoon, where mortality was $61 \%$ in the first night after settlement (Doherty et al. 2004). Unfortunately, growth and mortality are difficult to quantify and tradeoffs may exist between these 2 factors. Habitats offering high survival rates may not provide juveniles with high growth rates, and vice versa (e.g. Dahlgren \& Eggleston 2000). Habitat-specific growth rates and survival rates may change from place to place, over time, across density gradients, or as individuals grow. Thus, assessing only one of these factors to make inferences about the nursery function of habitats may be insufficient and misleading. Furthermore, even when growth and mortality rates are known, the nursery function of habitats can only be assumed or inferred because connectivity has not been established.

So how can we determine ontogenetic connectivity? Ontogenetic connectivity and nursery function of habitats within back-reef systems has been inferred by studying spatial and temporal patterns in the size distribution of species in different juvenile and adult habitats. For example, the fact that 4 dominant species (Lutjanus griseus, L. apodus, Haemulon sciurus, Sphyraena barracuda) are present almost exclusively as late-stage juveniles in well-developed Florida Bay and Biscayne Bay mangrove habitats (Ley et al. 1999, Ley \& McIvor 2002, Serafy et al. 2003, Eggleston et al. 2004), but spawn and occur as adults on Florida Keys reefs suggests habitat connectivity. In Curaçao and Bonaire (Netherlands Antilles), the complete fish fauna was investigated in up to 6 different back-reef system habitats and on the adjacent coral reef (Nagelkerken et al. 2000b, Nagelkerken \& van der Velde 2002, 2003). Of the 85 coral reef fish species observed, at least 17 species were found only as juveniles in the back-reef system and only as adults on the coral reef, suggesting habitat connectivity, particularly for several abundant and commercially important species. Numerous studies have demonstrated a relationship between the availability of juvenile habitat and the abundance of adults on nearby reefs (Baran \& Hambrey 1998, Nagelkerken et al. 2000b, 2002, Adams \& Ebersole 2004, Dorenbosch et al. 2004b, Halpern 2004, Mumby et al. 2004). However, all these findings are correlative, and do not explicitly demonstrate connections between juvenile and adult habitats. Inference about connectivity from spatial and temporal patterns in the size-distribution of species in different juvenile and adult habitats has also been used to show how availability of high quality juvenile habitat, or lack thereof, can decouple adult abundances from larval supply to an area (Lipcius et al. 1997).

While studies inferring juvenile contributions to adult populations for different habitats within backreef systems by comparing length-frequency distributions and by assessing density, growth and survival are useful, it is optimal to directly measure connectivity using artificial and natural habitat-specific markers (e.g. Yamashita et al. 2002, Chittaro et al. 2004). Below, we discuss factors potentially influencing the measurement of habitat-specific connectivity and the nursery function. Following this discussion, we provide and recommend a four-level research framework with which to pursue investigations of the nursery function.

\section{FACTORS INFLUENCING MEASUREMENT OF NURSERY FUNCTION}

\section{Life-history definitions}

Knowledge of the life history of a species is critical to understanding the nursery function of different habitats. Most coral reef fishes and many invertebrates have a 2-phase life cycle that may decouple local reproduction from recruitment into the local population, in which juveniles and adults are demersal and larvae are planktonic. The life history strategies of these fishes can be divided into 3 general categories based on patterns of habitat use during the benthic phase of their life history. First is the strategy whereby all benthic life stages use the same habitat, and ontogenetic shifts are minor ('habitat specialists': Fig. 1A). Habitat specialists tend to be site-attached, and settle, mature and reproduce in a single location (e.g. territorial pomacentrids; Doherty 1983). The second general strategy is followed by species that are not siteattached and can use a variety of habitats ('habitat generalists': Fig. 1B) (e.g. Halichoeres bivittatus; Sponaugle \& Cowen 1997). While ontogenetic shifts may occur for these species, they may not follow welldefined patterns and are minor relative to the third strategy. In the third strategy, species exhibit complex habitat, diet and behavioral shifts during the transition from settlement through late-juvenile life stages 


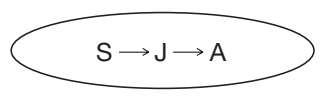

B
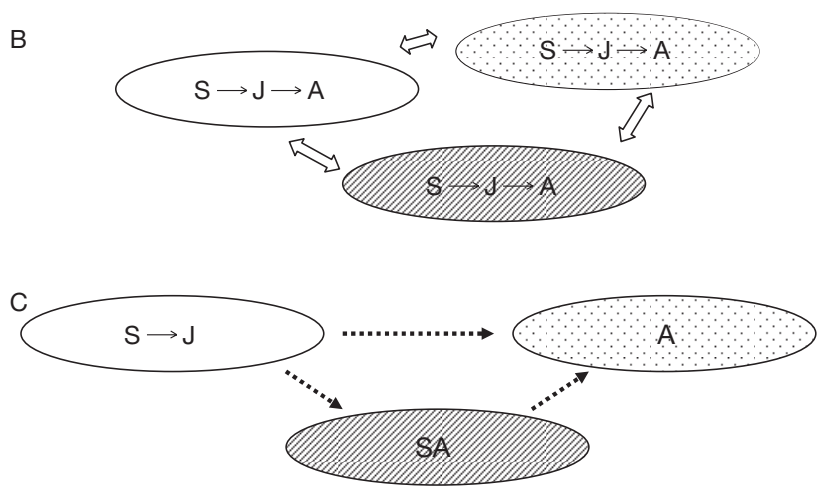

Fig. 1. Habitat use strategies for benthic periods of life history. (A) Habitat specialists: organisms use same habitat for all life stages; (B) habitat generalists: species are not site-attached and can utilize variety of habitats, an individual or different individuals within a population utilize multiple habitat types; (C) ontogenetic shifters: species exhibit habitat (as well as diet and behavioral) shifts during transition from settlement to adulthood. S: settlement; $\rightarrow$ : growth and ageing; J: juvenile stage; SA: subadult stage; A: adult stage; ovals with different shadings represent different habitats, outline-arrows represent non-ontogenetic movements and dashed arrows ontogenetic migrations between habitats

('ontogenetic shifters': Fig. 1C). Larvae of these species tend to settle into habitats that are distinct from adult habitats, and undergo notable ontogenetic shifts, often using intermediate habitats during this transition. Many of the species that use this life-history strategy use back-reef systems as juveniles (e.g. Serranidae:
Eggleston 1995, Sheaves 1995, St. John 1999; Haemulidae (Pomadasyidae): Shulman \& Ogden 1987, Appeldoorn et al. 1997; Lutjanidae: Ley et al. 1999; Palinuridae: Marx \& Herrnkind 1985, Acosta 1999, Eggleston \& Dahlgren 2001). Ontogenetic shifters that are exploited require especially expedient attention. Other species following this life history strategy may be of ecological importance in structuring fish assemblages and benthic communities (e.g. Sphyraenidae: Thayer et al. 1987, Ley et al. 1999, Acanthuridae: Robertson 1989, Adams \& Ebersole 2002, 2004).

For most species, the nursery function of back-reef system habitats remains unclear, in part because confusion has resulted from inconsistent definitions in the literature (especially between fishes and invertebrates) or definitions that have not sufficiently partitioned the early life stages of ontogenetic shifting species. Since nursery function comparisons should only be made among habitats utilized by the same life history stage of a given species, it is crucial to clearly delineate these stages (see Table 1).

Similarly, most work has also inadequately partitioned the life stages between recruitment and adult. In many cases, 'juvenile' has encompassed all life stages after settlement and prior to maturity (e.g. St. John 1999). Given the numerous ontogenetic shifts during the juvenile period (e.g. Epinephelus striatus: Eggleston 1995, Dahlgren \& Eggleston 2000, 2001), and because some species move from the back-reef systems to coral reefs prior to maturity (Adams \& Ebersole 2002, 2004, Cocheret de la Morinière et al. 2002), a more precise partitioning of this early life period is necessary (Shulman \& Ogden 1987, Robertson \& Kaufmann 1998).

Table 1. Summary of pre-juvenile life-history stage definitions

\begin{tabular}{|c|c|c|}
\hline Term & Definition & Source \\
\hline Settlement & $\begin{array}{l}\text { Initial establishment of larvae onto benthic substrate. Includes } \\
\text { only larval processes }\end{array}$ & $\begin{array}{l}\text { Kaufman et al. (1992), } \\
\text { Gutierrez (1998) }\end{array}$ \\
\hline Post-settlement transition & $\begin{array}{l}\text { Occurs during and immediately following settlement. Late- } \\
\text { stage larvae explore and evaluate benthic habitats (and may } \\
\text { re-enter pelagic environment several times), undergo meta- } \\
\text { morphosis, and become part of benthic population }\end{array}$ & $\begin{array}{l}\text { Kaufman et al. (1992), } \\
\text { McCormick \& Makey (1997) } \\
\text { Makey (1997), Sancho et al. } \\
(1997)\end{array}$ \\
\hline Post-settlement stage & $\begin{array}{l}\text { Time period directly after metamorphosis. A period of high } \\
\text { mortality. Duration varies among species due to different } \\
\text { susceptibility to predation }\end{array}$ & $\begin{array}{l}\text { Doherty \& Sale (1985), } \\
\text { Sogard (1997) }\end{array}$ \\
\hline Recruitment & $\begin{array}{l}\text { Occurs at end of post-settlement stage and incorporates } \\
\text { effects of larval and post-settlement processes. Characterized } \\
\text { by entrance into period of lower mortality. First record of an } \\
\text { individual in juvenile stage by researchers }\end{array}$ & $\begin{array}{l}\text { Doherty \& Sale (1985), } \\
\text { Kaufman et al. (1992), } \\
\text { Booth \& Brosnan (1995), } \\
\text { Gutierrez (1998) }\end{array}$ \\
\hline
\end{tabular}




\section{Ecological processes}

A difficult aspect in defining the nursery function of habitats is that many species show considerable plasticity in habitat use as juveniles. Some species, for example, may be obligatory users of particular juvenile habitats in one location (e.g. Ocyurus chrysurus dependent upon mangrove/seagrass habitat; Nagelkerken et al. 2001), but in another location use additional habitats as juveniles (e.g. juvenile O. chrysurus present in backreef system habitats lacking mangroves; Mateo \& Tobias 2001, Adams \& Ebersole 2002). Moreover, many species are abundant in numerous habitats as juveniles (Shulman \& Ogden 1987, Booth \& Wellington 1998, Nagelkerken et al. 2000b, Adams \& Ebersole 2002), suggesting a facultative strategy of habitat use.

Fishes and invertebrates tend to use shelter appropriate to their body size, and predation-induced competition may result in shelter of appropriate size being a limiting resource (Hixon 1991, Eggleston \& Lipcius 1992, Friedlander \& Parrish 1998). Moreover, juvenile habitat use can vary among locations (Booth \& Wellington 1998, Stoner 2003) and years (Tolimieri 1995, Adams \& Ebersole 2004), so caution should be exercised when attempting to extrapolate results across spatial and temporal scales. This inherent variability may limit the general applicability of results until information on connectivity between the various juvenile habitats and adult populations is established, which will help determine the extent to which juvenile habitats are obligatory or facultative.

Although difficult to measure, site selection at settlement by incoming larvae is likely to have variable effects on the distribution of juveniles. The ability of settlement-stage larvae to detect habitats prior to settlement (e.g. Montgomery et al. 2001, Atema et al. 2002) and evaluate habitats during settlement (Kaufman et al. 1992), combined with the plasticity of settlement preferences among individuals and among locations (Booth \& Wellington 1998), underscores the importance of examining the habitat characteristics that influence settlement and post-settlement movements. For site-attached species, site selection at settlement is reflected in juvenile abundance (e.g. Doherty 1983). In contrast, many fishes that are ontogenetic shifters undergo migrations immediately after settlement (McFarland 1980, Shulman \& Ogden 1987). Thus, a survey at the end of the summer settlement season in the Caribbean, for example, would reveal juvenile habitat use after potentially major postsettlement modification of settlement patterns (Shulman \& Ogden 1987, Booth \& Wellington 1998), and would omit important ontogenetic transitions.

Numerous post-settlement processes, which may be density-dependent, influence juvenile abundance, growth, survival and emigration, all of which combine to influence the nursery function. Predation is a major influence on juvenile fish abundance both through natural causes (e.g. Shulman 1984, 1985, Hixon \& Beets 1993, Sweatman \& Robertson 1994, Beukers \& Jones 1997, Nanami \& Nishihira 2001) and through fishing pressure (Heupel \& Simpfendorfer 2002). Other important factors influencing juvenile abundance are competition (Robertson 1991, Risk 1997, Overholtzer \& Motta 1999), other interspecific interactions (e.g. aggressive interactions: Overholtzer \& Motta 1999, Tolimieri 1998) and food availability (Shulman 1985, Heck \& Weinstein 1989, Ley et al. 1994, Laegdsgaard \& Johnson 1995, 2001, Nagelkerken et al. 2000a, but see Sheridan \& Hays 2003). However, the migratory ability of juveniles of many ontogenetic-shifting species (e.g. Blackmon \& Eggleston 2001) adds another aspect to the interpretation of research results. What has not been examined is whether migratory ability influences the effect/intensity of density-dependent mortality, and is in itself driven by site-specific densities. In other words, at what point and to what extent will juveniles risk migrating in search of other locations if conditions at one location are poor? What proportion of reduction in abundance that has been attributed to predation might actually have been due to migration? One approach to addressing this issue is examining foraging efficiency (Laegdsgaard \& Johnson 1995, 2001), changes in diet (Austin \& Austin 1971, Bellwood 1988, St. John 1999, Cocheret de la Morinière et al. 2003), and the tradeoffs between achieving a high growth rate and avoiding predation (Dahlgren \& Eggleston 2000) that are likely to underlie key ontogenetic transitions and provide insight into the relative influences of predation versus migration.

Ecological theory related to species that shift habitats suggests that the ontogenetic habitat shifts from back-reef systems to adult habitats can result from the conflicting demands of growth and survival that vary between habitats and change throughout an animal's ontogeny. Because different habitats vary in the quantity and quality of food and refuge and predation potential, for any species there may be tradeoffs between achieving a high growth rate and improving the chance of survival. As animals grow, their resource requirements for growth and their vulnerability to predators change. Thus, it is predicted that animals will change their habitat throughout their ontogeny to balance these tradeoffs by minimizing the ratio of mortality risk to growth rate (Werner \& Gilliam 1984). Theory also predicts that habitat shifts may result from behavioral responses to densitydependent resource use. For example, under the 'ideal free-distribution theory' (Fretwell \& Lucas 1970), individuals will choose to use a habitat that 
maximizes resource use of individuals, and change habitats when per capita resource availability increases in one habitat relative to another. Thus, animals may use poor-quality habitats when densities are high in high-quality habitats because per capita resource use will be similar in both habitats, but such poor-quality habitats may not be used when densities are low in better habitats. While tests of these theories in other marine systems indicate that such processes can drive habitat shifts (e.g. Holbrook \& Schmitt 1988, Salvanes et al. 1994, Utne \& Aksnes 1994), few empirical tests of these theories for ontogenetic habitat shifts exist for tropical marine species. Dahlgren \& Eggleston (2000) found ontogenetic habitat shifts by juvenile Nassau groupers Epinphelus striatus to be consistent with the predictions that ontogenetic habitat shifts minimize the ratio of mortality risk to growth rate. However, other studies have shown that movement among habitats was not density-dependent or related to per capita resource consumption as predicted by the ideal free-distribution theory (Levin et al. 2000, Overholzer-McLeod 2004, 2005).

Although it has received relatively little attention, understanding the effect of disturbances on the nursery function is critical. Butler et al. (1995) found that the distribution of juvenile Caribbean spiny lobsters among habitats changed dramatically when one of their preferred habitats, sponges, suffered a massive die-off in Florida Bay. In areas where few alternative natural or artificial shelters existed, lobster density decreased, but sites to which artificial shelters were added had a dramatic increase in lobster density.

Tropical cyclones are among the most prevalent disturbances to back-reef systems, and have an impact on the nursery function of habitats. Extremely high settlement of juvenile Epinephelus merra (up to 474 ind. per $20 \mathrm{~m}^{2}$ ) occurred in a pulse following a tropical storm on reefs of Réunion Island (Letourneur et al. 1998), but densities were reduced to pre-storm levels (18 ind. per $20 \mathrm{~m}^{2}$ ) within $7 \mathrm{wk}$. Thus density-dependent processes may impose a relatively stable density of the territorial E. merra (Letourneur et al. 1998). Lassig (1983) found high juvenile mortality and redistribution of subadults immediately after a tropical cyclone that occurred during the settlement season in Australia. Given the frequency of cyclones during the settlement season and the influence of recruitment on adult abundance, he postulated that cyclones might be important factors in population structure. In contrast, Adams \& Ebersole (2004) censused fishes before and after a hurricane that occurred at the end of the settlement season in the Caribbean, and found no short-term effects on abundance or size of studied species. They postulated that larger individuals present at the end of the settlement season may be resistant to hurricane disturbances. Alternatively, the high frequency of storms at their study location may have already induced a phase shift to fish assemblages resistant to hurricanes. Finally, effects of anthropogenic impacts on back-reef systems will probably be less variable because most of these impacts are long-term (chronic) and do not provide the opportunity for affected habitats to recover.

\section{Influence of habitat dispersion}

As indicated by our previous lagoon example, the loose use of habitat terms to describe potentially distinct habitat types has inhibited movement towards a consensus on the nursery function of back-reef system habitats. The lack of definition of habitat types within back-reef systems has sometimes resulted in wrong conclusions. Studies regularly refer to earlier work by, for example, Ogden \& Ehrlich (1977), Ogden \& Zieman (1977), McFarland (1980) and Myer et al. (1983) when discussing fish migrations from seagrass in back-reef systems to offshore coral reefs. The studies cited were done on patch reefs within a lagoon on St. Croix, however, and thus show the existence of ontogenetic migrations among habitats within the back-reef system instead of between the back-reef system and the coral reef. Confusion regarding habitat classification can be resolved, and comparisons within and among studies made consistent, if consensus can be reached regarding habitat classification schemes. Excellent examples of such schemes include those developed by the US National Ocean Service's Biogeography Team (http:// biogeo.nos.noaa.gov/products/us_pac_terr/htm/descri p.htm), the European Environment Agency (EUNIS, with input from BioMar; see http://eunis.eea.eu.int/ habitats.jsp), and Greene et al. (1999; for deep-sea habitats).

Descriptions of dispersion of habitat types in the overall habitat mosaic will also eliminate much of the confusion related to habitat classification. Habitat dispersion can affect the extent to which fishes are able to find appropriate back-reef system habitats for settlement, use back-reef system habitats as nurseries, and migrate to adult habitats on reefs (Booth \& Wellington 1998). For example, juveniles on similar habitat types at different distances from a coral reef experienced different predation rates (Shulman 1985). Within a lagoon, densities of reef fish species that typically spend their benthic life stages on the coral reef rapidly decrease with distance from the coral reef (Nagelkerken et al. 2000b). Juvenile immigration and emigration rates of spiny lobsters Panulirus argus in Belize were up to 4 times higher on mangrove and coral islands surrounded by seagrass (a settlement habitat) 
than on mangrove and coral islands surrounded by sand and rubble (Acosta 1999).

Although contiguous habitats are advantageous to vagile species that are able to move among these habitats (Ault \& Johnson 1998), especially as adults, the effects of habitat contiguity on ontogenetic shifts from juvenile to adult are unclear. For example, while some temperate species are capable of long-distance migrations between juvenile and adult habitats (Gillanders \& Kingsford 2000), this has seldom been shown for coral reef fishes. Also unclear is the extent to which habitat corridors are necessary for successful migration from isolated juvenile to adult habitats, but indications are that juveniles are able and willing to migrate among such isolated habitats. For example, acanthurid (Robertson 1989, Adams \& Ebersole 2002) and haemulid (McFarland 1980) larvae may take advantage of a large target area provided by seagrass beds for settlement, and then migrate to advantageous postsettlement microhabitat types (e.g. patch reefs, rubble) that are embedded within the seagrass beds (Parrish 1989). In this fashion, larvae are able to settle on habitat types that are close enough to the coral reef for successful ontogenetic migration, but far enough to reduce predation. More vagile species are able to use multiple, back-reef system habitat types within the juvenile stage, prior to shifting to deeper, open-water habitats as adults (e.g. Caranx ignobilis; Wetherbee et al. 2004). In contrast, the presence of less mobile species on isolated microhabitats (e.g. Nanami \& Nishihira 2002, 2003, Chittaro \& Sale 2003) is based in large part on the ability of larvae to find and settle on these habitats.

Finally, habitat complexity is especially influential in obtaining accurate measures of the nursery function. Such complexity results from not only the dispersion of habitats, but also from variability in characteristics of the habitat that affect its function for juveniles and the amount of habitat available to juveniles. While qualitative surveys have been conducted for most of the habitat types within back-reef systems, quantitative surveys have seldom been reliably accomplished. A further challenge involves the need to adequately characterize temporal variation in habitat characteristics and use, over both the shortand long-term.

\section{Geographical considerations}

Although back-reef systems may be important components of coral reef ecosystems worldwide, most of the literature, and most of the references cited here, are on the Caribbean. Historically, most Indo-Pacific studies have not compared juvenile use of habitats on the fore-reef and in back-reef systems, leaving unresolved the debate over the nursery function of the latter (Birkeland \& Amesbury 1988, Thollot \& Kulbicki 1989, Blaber \& Milton 1990, Chong et al. 1990, Thollot 1993). Evidence is growing, however, that back-reef system habitats in the Indo-Pacific may provide a nursery function similar to that found in the Caribbean. Many of the earlier studies indicating that backreef systems were important to reef fish populations focused on the importance of estuaries. For example, in north Australia, 11 species exclusively use estuaries as juveniles and offshore habitats as adults, suggesting a true estuarine-dependence (Blaber et al. 1989). Similarly, in eastern Australia, juveniles of at least 14 species occur in estuarine and adjacent, shallow, turbid mangrove and seagrass-bed habitats, with adults found in deeper water or ocean habitats (Blaber \& Blaber 1980). Mainland estuaries adjacent to the Barrier Reef were important nursery areas for Lutjanus russelli, L. argentimaculatus, Epinephelus coioides and E. malabaricus (Sheaves 1995). More recently, nonestuarine back-reef system habitats have been determined important juvenile habitats for species that live on the reef as adults (Doherty 2002, Nakamura \& Sano 2004, Doherty et al. 2004). Thus, although the following discussion of a suggested research framework draws on many examples from the Caribbean, the same generalized approach is recommended for Indo-Pacific studies.

\section{RECOMMENDED RESEARCH FRAMEWORK}

Given the lack of baseline data on juvenile habitat use for many species in back-reef systems, and the need for quantification of connectivity between juvenile and adult habitats, we build upon the framework presented by Beck et al. (2001) and suggest a 4-level approach to improve our understanding of the nursery function of back-reef system habitats (e.g. Platt 1964). We provide additional examples, primarily from the more extensive Caribbean literature, as cautions and to highlight how specific approaches can be used to assess habitatspecific nursery function for back-reef systems of coral reefs (Table 2).

\section{Level 1: building conceptual models}

There is considerable temporal and spatial variability in habitat use patterns and the habitat-specific nursery function. However, it is assumed that, on aver- 
Table 2. Summary of research recommendations and examples of application of research approaches in back-reef systems

\begin{tabular}{|c|c|c|}
\hline Research level & Examples & Source \\
\hline \multicolumn{3}{|c|}{ 1. Developing models of nursery function } \\
\hline A. Conceptual models & Strombus gigas & Stoner (2003) \\
\hline \multicolumn{3}{|c|}{ 2. Identifying distribution patterns among multiple juvenile habitats } \\
\hline \multirow{3}{*}{$\begin{array}{l}\text { A. Habitat-specific juvenile } \\
\text { abundance or density }\end{array}$} & Epinephelus striatus & Eggleston (1995), Dahlgren \& Eggleston (2001) \\
\hline & Labridae & Sponaugle \& Cowen (1997) \\
\hline & Reef fishes (several species) & $\begin{array}{l}\text { Nagelkerken et al. (2000b), Nagelkerken \& van der Velde } \\
(2002,2003) \text {, Adams \& Ebersole }(2002,2004), \text { Eggleston et al. } \\
(2004)\end{array}$ \\
\hline \multicolumn{3}{|c|}{ 3. Quantifying connectivity or habitat-specific contribution of juveniles to adult populations for multiple habitats } \\
\hline $\begin{array}{l}\text { A. Distribution of habitat- } \\
\text { specific natural markers } \\
\text { in adult populations }\end{array}$ & Haemulon flavolineatum & Chittaro et al. (2004) \\
\hline $\begin{array}{l}\text { B. Artificial tagging } \\
\text { experiments }\end{array}$ & $\begin{array}{l}\text { No known examples from } \\
\text { back-reef systems }\end{array}$ & $\begin{array}{l}\text { See Gillanders et al. (2003) for discussion of tagging in } \\
\text { temperate systems }\end{array}$ \\
\hline \multicolumn{3}{|c|}{ 4. Examining habitat-moderated ecological processes in multiple habitats } \\
\hline $\begin{array}{l}\text { A. Habitat selection at } \\
\text { settlement }\end{array}$ & Reef fish & Kaufman et al. (1992), Atema et al. (2002) \\
\hline \multirow{2}{*}{$\begin{array}{l}\text { B. Habitat-specific growth } \\
\text { rates }\end{array}$} & Epinephelus striatus & Dahlgren \& Eggleston (2000) \\
\hline & Strombus gigas & $\begin{array}{l}\text { Stoner \& Sandt (1991), Sandt \& Stoner (1993), Stoner \& Ray } \\
\text { (1993), Ray \& Stoner (1995) }\end{array}$ \\
\hline \multirow{3}{*}{$\begin{array}{l}\text { C. Habitat-specific mortality } \\
\text { rates }\end{array}$} & Epinephelus striatus & Dahlgren \& Eggleston (2000) \\
\hline & Reef fish & Shulman (1985) \\
\hline & Strombus gigas & Stoner \& Sandt (1991), Stoner \& Ray (1993), Ray \& Stoner (1995) \\
\hline $\begin{array}{l}\text { D. Within- and between- } \\
\text { habitat movement }\end{array}$ & Strombus gigas & Stoner \& Ray (1993) \\
\hline
\end{tabular}

age, particular habitat types have a higher nursery function than others (Beck et al. 2001). Therefore, it is helpful to develop a conceptual model (e.g. Odum 1983, Grant et al. 1997) that provides a framework for evaluating habitats and determining the nursery function in this dynamic context. In addition, a conceptual model is adaptable in that it can be modified as new information is gained. Perhaps most important, however, is that a conceptual model is useful in making predictions about habitat-specific nursery function, and underlying processes, that can be tested at multiple scales and in multiple locations. The building of conceptual models should be an iterative process initially based upon present knowledge, with subsequent data collection and hypothesis testing, and adjustment of the model accordingly.

\section{Level 2: identifying patterns}

With guidance from conceptual models developed in Level 1, Level 2 research identifies general patterns of habitat-specific density; i.e. quantify the abundance of each life history stage of each species in each habitat within back-reef systems and adjacent coral reefs at multiple times. With this research it is important to use a comparative sampling approach so that all habitat types potentially used by the life stage of interest are sampled. Such comparative data will (1) be essential for testing hypotheses of proportional importance of different habitat types to each life stage (e.g. nursery habitat identification; Beck et al. 2001), (2) help to avoid the pitfalls that stem from sampling only a portion of habitats (Gillanders et al. 2003), and (3) provide a framework for examining processes that affect fishes within each habitat type (see subsection on Level 4).

Within this comparative sampling approach, it is critical to consider and correct for differences in gear efficiencies between habitats (e.g. Leber \& Greening 1986, Kellison et al. 2003) and for the use of different gears in different habitats (Rozas \& Minello 1998). Temporal biases (e.g. seasonal, diurnal) in sampling must also be carefully considered. For example, in the Caribbean, common fishes such as Lutjanidae and Haemulidae show diurnal movements between mangroves, seagrass beds and lagoonal patch reefs (Ogden \& Ehrlich 1977, Helfman et al. 1982, Rooker \& Dennis 1991, Nagelkerken et al. 2000a), while Scaridae (e.g. Scarus croicensis: Ogden \& Buckman 1973) use traditional migratory pathways between day feeding areas on the reef platform and night resting areas in deeper 
reef habitats. Stable isotope and gut content analyses on snappers and grunts collected from mangrove habitats also indicate multiple habitat use (Harrigan et al. 1989, Kieckbush et al. 2004, Nagelkerken \& van der Velde 2004). Therefore, while determination of habitat-specific growth, mortality and production rates (see Level 4 subsection) may be useful for some species, for many species that occupy back-reef systems these rates are probably the product of using multiple habitat types. This suggests that certain combinations of habitat types are perhaps more important than any single habitat type, especially during the juvenile and subadult stages when individuals may not so much 'shift' from mangrove to reef habitats as 'expand' to incorporate more habitats into their repertoire with increasing age (Serafy et al. 2003).

A second critical aspect of Level 2 research, largely lacking in studies in back-reef systems so far, is the application of the landscape theory (e.g. Robbins \& Bell 1994) and habitat dispersion to habitat utilization and production. While the structural components of a habitat will be important to its value as a juvenile habitat for a given species, the nursery function of a habitat may also be largely dependent on its location within the overall habitat mosaic (Stoner 2003), as discussed previously. It is important to consider spatial connectivity in a species-specific context, as the importance of habitat contiguity probably varies among species (Ault \& Johnson 1998, Cocheret de la Morinière et al. 2002).

Species that routinely utilize multiple habitat types should also be studied using landscape approaches in Level 2 research. For example, the approach by Kendall et al. (2003) in their work on the French grunt Haemulon flavolineatum demonstrates how data on patterns of habitat use can be incorporated into a larger-scale spatial context of habitat distributions. Kendall et al. (2003) demonstrated that juvenile French grunts require a particular mixture and proximity of both hard-bottom and soft-bottom habitats, but that adults seem to have fewer restrictions and show no such relationship. These patterns were only observed at particular scales of analysis, and were explained in the context of larval settlement patterns, ontogenetic shifts, and foraging and sheltering requirements of individual life stages. Thus, the concurrent use of in situ observations and habitat distribution data provides a framework for examining how the spatial distribution of habitats influences fish distributions (e.g. Lindeman et al. 1998 for grunts and snappers). Relationships between the fish community present at a given site and the elements of the surrounding landscape must be evaluated at appropriate spatial scales to detect correlations (Kendall 2005). While defining habitat-specific density for each life stage is an important component of Level 2 research, mapping the spa- tial dispersion of these habitats will provide the basis for additional Level 2 research on processes underlying habitat-specific densities, and Level 3 research on connectivity. Finally, defining the role of spatial context within the ecosystem habitat mosaic will provide a foundation for determining how a species might have been impacted by previous habitat fragmentation or loss (i.e. to what extent past habitat loss might be responsible for present population bottlenecks and trends in adult abundance), and what habitat(s) should be targeted for habitat restoration or conservation. This information will be especially important for the formulation of management and conservation plans that must incorporate ecological and anthropogenic components.

\section{Level 3: assessing habitat connectivity}

Once a quantitative baseline of habitat-specific patterns has been established, Level 3 research should examine connections among habitats and factors that might affect the observed patterns. Within the habitat mosaic defined in Level 2 research, Level 3 research should focus on establishing connections between juvenile habitats and habitats used by subadult and adult populations. This involves direct measurement of the extent to which these habitats are connected in order to estimate proportional contributions of the various juvenile habitats to adult populations (e.g. Chittaro et al. 2004). These measurements result in the truest measure of nursery function, and can be made with research utilizing artificial and natural tags (see Thorrold et al. 1998, 2002, Gillanders et al. 2003, Wetherbee et al. 2004). Such measurements should include landscape considerations, and should attempt to identify not only the type, but also the location of habitats from which adult production is derived.

Direct study of fish movements among habitat types can elucidate the mechanisms through which different habitat types are linked (Sale et al. 2005). This is most likely to be achieved through uninterrupted monitoring of the location and behavior of tagged individuals. Radio-telemetry tagging systems, for example, hold much promise for continuous tracking of individuals in space and time. For example, using this methodology, Szedlmayer \& Able (1993) demonstrated a seasonspecific ontogenetic habitat shift of summer flounder from tidal creeks into the marine environment. In practice, however, using telemetry to track an adequate number of individuals over relevant time periods and large spatial scales can be logistically and economically prohibitive. Similar benefits and constraints apply to various other natural and artificial tagging techniques (see complete review in Gillanders et al. 2003). Despite 
the challenges associated with directly demonstrating fish movement patterns, we call for renewed efforts to use these methodologies to provide a more thorough and direct description of fish movements among habitat types, and, ultimately, of the nursery function of specific habitats.

\section{Level 4: examining processes}

Level 4 research identifies the processes and mechanisms underlying patterns observed from Level 2 and Level 3 research, including those that influence or determine larval supply, settlement, movement, growth and survival for each life stage of a given species. At present, most information regarding the role of back-reef habitats as nursery areas is based on inference from patterns to process, e.g. using lengthfrequency histograms to infer ontogenetic habitat shifts in fish species. Level 4 research seeks to further elucidate patterns discerned in Level 2 and Level 3 research using direct demonstration or experimental manipulations of potential underlying mechanisms (Connell 1980, Simberloff 1983, Strong et al. 1984).

Experimental manipulations can be used to demonstrate explicitly the tradeoffs that determine habitat selection, growth, survival and movements of individual fish. For example, Dahlgren \& Eggleston (2000) used field caging and tethering experiments to test the mechanisms that influence movement among habitats for juvenile Nassau grouper Epinephelus striatus. These experiments sought a deeper understanding of observation-based studies that suggested ontogenetic habitat shifts by this species (Eggleston 1995, Dahlgren \& Eggleston 2001). Dahlgren \& Eggleston (2000) demonstrated that the ratio of mortality risk to growth rate was the critical factor determining habitat selection. This level of understanding, which links observed patterns to the processes that give rise to them, is critical to developing efficient conservation strategies for focal species.

At broad spatial scales, anthropogenic activities (e.g. habitat destruction or restoration), marine protected areas (MPAs), and natural disturbances (e.g. hurricanes) can be utilized as ecosystem-level experiments to evaluate hypothesized mechanisms in back-reef systems. For example, restoration of back-reef system habitats are an excellent 'acid test' of current ecological understanding (Bradshaw 1987). Efforts underway to restore hydrologic connectivity (i.e. tidal flow) to fragmented tidal creeks in the Bahamas (Layman et al. 2005) can be treated as experimental manipulations of entire back-reef systems. By tracking fish production and movement patterns following restoration, it may be possible to quantify the degree of faunal enhancement to adult populations (e.g. on coral reefs), and thus support or refute hypotheses con- cerning the effects of ecological processes occurring in these habitats. Similarly, MPAs can provide 'beforeafter' protection comparisons, or large-scale comparisons among protected and unprotected areas that reveal specific mechanisms that may be altered with varying degrees of human impact (Halpern \& Warner 2002, Sobel \& Dahlgren 2004, Micheli et al. 2005). Finally, natural disasters can be used to assess changes in the nursery function following habitat loss. For example, hurricane decimation of seagrass beds (Rodriguez et al. 1994, Fourqurean \& Rutten 2004) provides an opportunity to test hypotheses on the importance of these habitat types for increasing growth and survival of juvenile fishes (reviewed in Heck et al. 2003).

Temporal and spatial variability in habitat utilization patterns must be considered when planning future studies. Larval recruitment, for example, may vary annually by orders of magnitude (Shulman 1985), which may result in annual habitat-specific production differences for species that show plasticity in habitat use (e.g. Adams \& Ebersole 2004). From a spatial perspective, sites that seem to belong within the same habitat type (e.g. seagrass beds, mangrove edges, beaches) may be quite different due to location or other attributes, and might more appropriately be considered as distinct (e.g. small-patch versus large-patch seagrass beds, mainland shoreline versus island mangrove edges, high-energy versus low-energy beaches).

The above discussion has addressed the importance of comparisons among habitats, i.e. on the local scale, but it is equally essential to incorporate comparisons at the regional scale into research designs. Given the plasticity in habitat use by fishes of many species, it is possible that habitats are used at different levels in different regions (Gillanders et al. 2003); this is a good argument for concurrent research in multiple regions. Alternatively, sequentially repeating research in different regions, using conceptual models as a predictive framework, presents a perfect opportunity for testing hypotheses generated by research in a single region. Comparative results will help determine whether species are obligatory or facultative users of the identified juvenile habitats (e.g. Nagelkerken et al. 2001, 2002). In addition, comparisons among areas along a gradient from high to low anthropogenic impacts should provide immediate applications for management, conservation and restoration.

\section{MANAGEMENT RECOMMENDATIONS}

The research recommended herein for back-reef systems would provide information that would be beneficial to managers in 3 main areas: habitat conservation, habitat restoration and ecosystem management. From a 
habitat conservation and restoration perspective, knowledge of the nursery function of back-reef habitat types, fully quantified or relative to other back-reef habitat types, would allow managers to identify and target highly productive areas (nursery or effective juvenile habitats: Beck et al. 2001 and Dahlgren et al. 2006, respectively) for protection or restoration. Managers could also assess the success of restoration efforts by comparing measures of nursery function between restored and natural sites. From an ecosystem-management standpoint, knowledge of the habitat specific nursery function would (1) help to elucidate the importance and potential severity of habitat degradation, fragmentation, and loss to ecosystem services (a message that could be conveyed to the public via outreach efforts), and (2), allow managers to better predict multi-species population trends (assuming knowledge of the nursery function for multiple species) and implement adaptive management practices for species or groups of species of management interest.

Improving our ability to manage and conserve the goods and services provided by back-reef systems will also be dependent on increased cooperation and coordination between multiple local, regional, national and international management agencies with adjacent resource management and enforcement jurisdictions or, in many cases, overlapping jurisdictions. It has long been understood that, since many fishes and invertebrates move over relatively large spatial scales during the course of their life history, and jurisdictional boundaries are rarely based on biological factors, management of these species requires coordination across management boundaries. We must work to improve this coordination, ensuring that management, conservation and restoration goals and approaches are consistent across agencies.

Acknowledgements. This publication is part of a series of papers resulting from a scientific workshop held at NOAA's Undersea Research Center for the Caribbean on Lee Stocking Island (January 2005) to evaluate the importance of back-reef systems for supporting biodiversity and productivity of marine ecosystems. We thank D. Brown, J. Marr, S. Slingsby, B. Lumsden and staff of the Perry Institute for Marine Science for organizing the Back Reef Workshop II, which led to the publication of this paper, and B. Hatcher for commenting on an earlier version of this manuscript. This paper was prepared under award No. NA06RU0228 from the National Oceanic and Atmospheric Administration (NOAA), US Department of Commerce, and under EPA Assistance Agreement No. X783124201-0 to the Perry Institute for Marine Science. The statements, findings, conclusions, and recommendations are those of the authors and do not necessarily reflect the views of NOAA or EPA. Funding for manuscript preparation was provided to the authors by the Mote Scientific Foundation (A.J.A.), National Science Foundation OCE-0119976 (C.P.D.), and a Vidi grant from the Netherlands Organization for Scientific Research (I.N.).

\section{LITERATURE CITED}

Acosta CA (1999) Benthic dispersal of Caribbean spiny lobsters among insular habitats: implications for the conservation of exploited marine species. Conserv Biol 13: 603-612

Adams AJ, Ebersole JP (2002) Use of back-reef and lagoon habitats by coral reef fishes. Mar Ecol Prog Ser 228: 213-226

Adams AJ, Ebersole JP (2004) Processes influencing recruitment inferred from distributions of coral reef fishes. Bull Mar Sci 75:153-174

Adams AJ, Tobias WJ (1999) Red mangrove prop-root habitat as a finfish nursery area: a case study of Salt River Bay, St. Croix, USVI. Proc Gulf Caribb Fish Inst 46:22-46

Appeldoorn RS, Recksiek CW, Hill RL, Pagan FE, Dennis GD (1997) Marine protected areas and reef fish movements: the role of habitat in controlling ontogenetic migration. Proc 8th Int Coral Reef Symp 2:1917-1922

Atema J, Kingsford MJ, Gerlach G (2002) Larval reef fish could use odour for detection, retention and orientation to reefs. Mar Ecol Prog Ser 241:151-160

Ault TR, Johnson CR (1998) Relationships between habitat and recruitment of three species of damselfish (Pomacentridae) at Heron Reef, Great Barrier Reef. J Exp Mar Biol Ecol 223:145-166

Austin HE (1971) A survey of the ichthyofauna of the mangroves of western Puerto Rico during December, 1967August, 1968. Caribb J Sci 11:27-39

Austin HM, Austin SE (1971) The feeding habits of some juvenile marine fishes from the mangroves in western Puerto Rico. Caribb J Sci 11:171-178

Baran E, Hambrey J (1998) Mangrove conservation and coastal management in southeast Asia: what impact on fishery resources? Mar Pollut Bull 37:431-440

Beach D (2002) Coastal sprawl: the effects of urban design on aquatic ecosystems in the United States. Pew Oceans Commission, Arlington, VA. (available online at http:// www.pewtrusts.org/pdf/ env_pew_oceans_sprawl.pdf)

Beck MW, Heck KL, Able KW, Childers DL and 9 others (2001) The identification, conservation, and management of estuarine and marine nurseries for fish and invertebrates. BioScience 51:633-641

Beck MW, Heck KL Jr, Able KW, Childers DL and 9 others (2003) The role of nearshore ecosystems as fish and shellfish nurseries. Issues Ecol 11:1-12

Bellwood DR (1988) Ontogenetic changes in the diet of early post-settlement Scarus species. J Fish Biol 33:213-219

Beukers JS, Jones GP (1997) Habitat complexity modifies the impact of piscivores on a coral reef fish population. Oecologia 114:50-59

Birkeland C, Amesbury SS (1988) Fish-transect surveys to determine the influence of neighboring habitats on fish community structure in the tropical Pacific. In: Co-operation for environmental protection in the Pacific. UNEP Reg Seas Rep Stud 97:195-202

Blaber SJM, Blaber TG (1980) Factors affecting the distribution of juvenile estuarine and inshore fish. J Fish Biol 17: 143-162

Blaber SJM, Milton DA (1990) Species composition, community structure and zoogeography of fishes of mangrove estuaries in the Solomon Islands. Mar Biol 105:259-267

Blaber SJM, Brewer DT, Salini JP (1989) Species composition and biomasses of fishes in different habitats of a tropical northern Australian estuary: their occurrence in the adjoining sea and estuarine dependence. Estuar Coast Shelf Sci 29:509-531 
Blackmon DC, Eggleston DB. (2001) Factors influencing planktonic, post-settlement dispersal of early juvenile blue crabs (Callinectes sapidus Rathbun). J Exp Mar Biol Ecol 257:183-203

Booth DJ, Brosnan DM (1995) The role of recruitment dynamics in rocky shore and coral reef fish communities. Adv Ecol Res 26:309-385

Booth DJ, Wellington GW (1998) Settlement preferences in coral reef fishes: effects on patterns of adult and juvenile distributions, individual fitness, and population structure. Aust J Ecol 23:274-279

Bradshaw AD (1987) Restoration: an acid test for ecology. In: Jordan WR, Gilpin ME, Aber JD (eds) Restoration ecology. Cambridge University Press, Cambridge, UK

Butler MJ, Hunt JH, Herrnkind WF, Childress MJ and 5 others (1995) Cascading disturbances in Florida Bay, USA: cyanobacteria blooms, sponge mortality, and implications for juvenile spiny lobsters Panulirus argus. Mar Ecol Prog Ser 129:119-125

Chittaro P, Sale PF (2003) Structure of patch-reef fish assemblages at St. Croix, US Virgin Islands and One Tree Reef, Australia. Mar Ecol Prog Ser 249:277-287

Chittaro PM, Fryer BJ, Sale PF (2004) Discrimination of French grunts (Haemulon flavolineatum, Desmarest, 1823) from mangrove and coral reef habitats using otolith microchemistry. J Exp Mar Biol Ecol 308:169-183

Chong VC, Sasekumar A, Leh MUC, D'Cruz R (1990) The fish and prawn communities of a Malaysian coastal mangrove systems, with comparisons to adjacent mudflats and inshore waters. Estuar Coast Shelf Sci 31:703-722

Cocheret de la Morinière E, Pollux BJA, Nagelkerken I, van der Velde G (2002) Post-settlement life cycle migration patterns and habitat preference of coral reef fish that use seagrass and mangrove habitats as nurseries. Estuar Coast Shelf Sci 55:309-321

Cocheret de la Morinière E, Pollux BJA, Nagelkerken I, van der Velde G (2003) Diet shifts of Caribbean grunts (Haemulidae) and snappers (Lutjanidae) and the relation with nursery-to-coral reef migrations. Estuar Coast Shelf Sci 57:1079-1089

Coen JE, Small C, Mellenger A, Gallup J, Sachs J (1997) Letter to the editor. Science 278:1209

Connell JH (1980) Diversity and coevolution of competitors, or the ghost of competition past. Oikos 35:131-138

Dahlgren CP, Eggleston DB (2000) Ecological processes underlying ontogenetic habitat shifts in a coral reef fish. Ecology 81:2227-2240

Dahlgren CP, Eggleston DB (2001) Spatio-temporal variability in abundance, size, and microhabitat associations of early juvenile Nassau grouper Epinephelus striatus in an offreef nursery system. Mar Ecol Prog Ser 217:145-156

Dahlgren CP, Marr J (2004) Back reef systems: important but overlooked components of tropical marine ecosystems. Bull Mar Sci 75:145-152

Doherty PJ (1983) Diel, lunar and seasonal rhythms in the reproduction of two tropical damselfishes: Pomacentrus flavicauda and $P$. wardi. Mar Biol 75:215-224

Dahlgren CP, Kellison GT, Adams AJ, Gillanders BM and 5 others (2006) Marine nurseries and effective juvenile habitats: concepts and applications. Mar Ecol Prog Ser 312: 291-295

Doherty PJ (2002) Variable replenishment and the dynamics of reef fish populations. In: Sale P (ed) Coral reef fishes: dynamics and diversity in a complex ecosystem. Academic Press, New York

Doherty PJ, Sale PF (1985) Predation on juvenile coral reef fishes: an exclusion experiment. Coral Reefs 4:225-234
Doherty PJ, Dufour V, Galzin R, Hixon MA, Meekan MG, Planes S (2004) High mortality during settlement is a population bottleneck for a tropical surgeonfish. Ecology 85:2422-2428

Dorenbosch M, van Riel MC, Nagelkerken I, van der Velde G (2004a) The relationship of reef fish densities to the proximity of mangrove and seagrass nurseries. Estuar Coast Shelf Sci 60:37-48

Dorenbosch M, Verweij MC, Nagelkerken I, Jiddawi N, van der Velde G (2004b) Homing and daytime tidal movements of juvenile snappers (Lutjanidae) between shallowwater nursery habitats in Zanzibar, western Indian Ocean. Environ Biol Fish 70:203-209

Eggleston DB (1995) Recruitment in Nassau grouper Epinephelus striatus: post-settlement abundance, microhabitat features, and ontogenetic habitat shifts. Mar Ecol Prog Ser 124:9-22

Eggleston DB, Dahlgren CP (2001) Distribution and abundance of Panulirus argus in the Key West National Wildlife Refuge: relationship to habitat features and impact of an intensive recreational fishery. Mar Freshw Res 52: $1567-1576$

Eggleston DB, Lipcius RN (1992) Shelter selection by spiny lobster under variable predation risk, social conditions and shelter size. Ecology 73:992-1011

Eggleston DB, Dahlgren CP, Johnson EG (2004) Fish density, diversity, and size-structure within multiple back reef habitats of Key West National Wildlife Refuge. Bull Mar Sci 75:175-204

Fourqurean JW, Rutten LM (2004) The impact of Hurricane Georges on soft-bottom, back reef communities: site- and species-specific effects in south Florida seagrass beds. Bull Mar Sci 75:239-257

Fretwell SD, Lucas HL (1970) On territorial behavior and other factors influencing habitat distribution in birds. Acta Biotheor 19:16-36

Friedlander AM, Parrish JD (1998) Habitat characteristics affected fish assemblages on a Hawaii coral reef. J Exp Mar Biol Ecol 224:1-30

Gillanders BM, Kingsford MJ (2000) Elemental fingerprints of otoliths of fish may distinguish estuarine nursery habitats. Mar Ecol Prog Ser 201:273-286

Gillanders BM, Able KW, Brown JA, Eggleston DB, Sheridan PF (2003) Evidence of connectivity between juvenile and adult habitats for mobile marine fauna: an important component of nurseries. Mar Ecol Prog Ser 247:281-295

Grant WE, Pedersen EK, Marín SL (1997) Ecology and natural resource management: systems analysis and simulation. Wiley, New York

Greene HG, Yoklavich MM, Starr RM, O'Connell VM, Wakefield WW, Sullivan DE, McRea JE Jr, Cailliet GM (1999) A classification scheme for deep seafloor habitats. Oceanol Acta 22:663-678

Gutierrez L (1998) Habitat selection by recruits establishes local patterns of adult distribution in two species of damselfishes: Stagastes dorsopunicans and S. planifrons. Oecologia 115:268-277

Halpern BS (2004) Are mangroves a limiting resource for two coral reef fishes? Mar Ecol Prog Ser 272:93-98

Halpern BS, Warner RR (2002) Marine reserves have rapid and lasting effects. Ecol Lett 5:361-366

Harrigan P, Zeiman JC, Macko SA (1989) The base of nutritional support for the gray snapper (Lutjanus griseus): an evaluation based on a combined stomach content and stable isotope analysis. Bull Mar Sci 44:65-77

Heck KL, Weinstein MP (1989) Feeding habits of juvenile reef fishes associated with Panamanian seagrass meadows. 
Bull Mar Sci 45:629-636

Heck KL, Nadeau DA, Thomas R (1997) The nursery role of seagrass beds. Gulf Mex Sci 1:50-54

Heck KL, Hays G, Orth RJ (2003) Critical evaluation of the nursery role hypothesis for seagrass meadows. Mar Ecol Prog Ser 253:123-136

Helfman GS, Meyer JL, McFarland WN (1982) The ontogeny of twilight migration patterns in grunts (Pisces, Haemulidae). Anim Behav 30:317-326

Heupel MR, Simpfendorfer CA (2002) Estimation of mortality of juvenile blacktip sharks, Carcharhinus limbatus, within a nursery area using telemetry data. Can J Fish Aquat Sci 59:624-632

Hinrichsen D (1998) Coastal waters of the world: trends, threats, and strategies. Island Press, Washington, DC

Hixon MA (1991) Predation as a process structuring coral reef fish communities. In: Sale PF (ed) The ecology of fishes on coral reefs. Academic Press, San Diego, CA, 475-505

Hixon MA, Beets JP (1993) Predation, prey refuges and the structure of coral reef fish assemblages. Ecol Monogr 63: 77-101

Holbrook SJ, Schmitt RJ (1988) The combined effects of predation risk and food reward on patch selection. Ecology 69:125-134

Hughes TP (1994) Catastrophes, phase shifts, and large-scale degradation of a Caribbean coral reef. Science 265: $1547-1551$

Jones GP, McCormick MI, Srinivasan M, Eagle JV (2004) Coral decline threatens fish biodiversity in marine reserves. Publ Nebraska Acad Sci 101:8251-8253

Kaufman LS, Ebersole J, Beets J, McIvor CC (1992) A key phase in the recruitment dynamics of coral reef fishes: post-settlement transition. Environ Biol Fish 34:109-118

Kellison GT, Eggleston DB, Taylor JC, Burke JS (2003) An assessment of biases associated with caging, tethering, and habitat-specific trawl sampling of summer flounder (Paralichthys dentatus). Estuaries 26:64-71

Kendall MS (2005) A method for investigating seascape ecology of reef fish. Proc Gulf Carib Fish Inst 56:1-11

Kendall MS, Christensen JD, Hillis-Starr Z (2003) Multi-scale data used to analyze the spatial distribution of French grunts, Haemulon flavolineatum, relative to hard and soft bottom in a benthic seascape. Environ Biol Fish 66:19-26

Kieckbush DK, Koch MS, Serafy JE, Anderson WT (2004) Trophic linkages of primary producers and consumers in fringing mangroves of tropical lagoons. Bull Mar Sci 74: 271-285

Laegdsgaard P, Johnson CR (1995) Mangrove habitats as nurseries: unique assemblages of juvenile fish in subtropical mangroves of eastern Australia. Mar Ecol Prog Ser 126:67-81

Laegdsgaard P, Johnson CR (2001) Why do juvenile fish utilize mangrove habitats? J Exp Mar Biol Ecol 257:229-253

Lapointe BE,Tomasko DA, Matzie WR (1994) Eutrophication and trophic state classification of seagrass communities in the Florida Keys. Bull Mar Sci 54:696-717

Lassig BR (1983) The effects of a cyclonic storm on coral reef fish assemblages. Environ Biol Fish 9:55-63

Layman CA, Arrington DA, Blackwell MA (2005) Community-based collaboration restores tidal flow to an island estuary (Bahamas). Ecol Res 23:58-59

Leber KM, Greening HS (1986) Community studies in seagrass meadows: a comparison of two methods for sampling macroinvertebrates and fishes. Fish Bull (Wash DC) 84:443-450

Letourneur Y, Chabanet P, Vigliola L, Harmelin-Vivien MTI (1998) Mass settlement and post-settlement mortality of
Epinephelus merra (Pisces: Serranidae) on Reunion coral reefs. J Mar Biol Assoc UK 78:307-319

Levin PS, Tolimieri N, Nicklin M, Sale PF (2000) Integrating individual behavior and population ecology: the potential for habitat-dependent population regulation in a reef fish. Behav Ecol 11:565-571

Ley JA, McIvor CC (2002) Linkages between estuarine and reef fish assemblages: enhancement by the presence of well-developed mangrove shorelines. In: Porter J, Porter K (eds) The Everglades, Florida Bay and coral reefs of the Florida Keys: an ecosystem sourcebook. CRC Press, Boca Raton, FL, p 531-554

Ley JA, Montague CL, McIvor CC (1994) Food habits of mangrove fishes: a comparison along estuarine gradients in northeastern Florida Bay. Bull Mar Sci 54:881-899

Ley JA, McIvor CC, Montague CL (1999) Fishes in mangrove prop root habitats of northeastern Florida Bay: distinct assemblages across an estuarine gradient. Estuar Coast Shelf Sci 48:710-723

Lindeman KC, Diaz GA, Serafy JE, Ault JS (1998) A spatial framework for assessing cross-shelf habitat use among newly settled grunts and snappers. Proc Gulf Caribb Fish Inst 50:385-416

Lipcius R, Stockhausen W, Eggleston D, Hickey B (1997) Hydrodynamic decoupling of spawning stock, habitat quality and recruitment in the Caribbean spiny lobster: source-sink dynamics? J Mar Freshw Res 48:807-815

Marx JM, Herrnkind WF (1985) Macroalgae (Rhodophyta: Laurencia spp.) as habitat for young juvenile spiny lobsters, Panulirus argus. Bull Mar Sci 36:423-431

Mateo I, Tobias W (2001) The role of nearshore habitats as nursery grounds for juvenile fishes on the northeast coast of St. Croix. Proc Gulf Caribb Fish Inst 52:512-530

McCormick MI, Makey LJ (1997) Post settlement transition in coral reef fishes: overlooked complexity in niche shifts. Mar Ecol Prog Ser 153:247-257

McFarland WN (1980) Observations on recruitment in Haemulid fishes. Proc Gulf Caribb Fish Inst 32:132-138

Meyer JL, Schultz ET, Helfman GS (1983) Fish schools: an asset to corals. Science 220:1047-1049

Micheli F, Benedetti-Cecchi L, Gambaccini S, Bertocci I, Borsini C, Osio GC, Roman F (2005) Cascading human impacts, marine protected areas, and the structure of Mediterranean reef assemblages. Ecol Monogr 75:81-102

Montgomery JC, Tolimieri N, Haine OS (2001) Active habitat selection by pre-settlement reef fishes. Fish Fish Ser 2: 261-277

Mumby PJ, Edwards AJ, Arias-Gonzalez JE, Lindeman KC adn 8 others (2004) Mangroves enhance the biomass of coral reef fish communities in the Caribbean. Nature 427: $533-536$

Nagelkerken I, van der Velde G (2002) Do non-estuarine mangroves harbour higher densities of juvenile fish than adjacent shallow-water and coral reef habitats in Curaçao (Netherlands Antilles)? Mar Ecol Prog Ser 245:191-204

Nagelkerken I, van der Velde G (2003) Connectivity between coastal habitats of two oceanic Caribbean islands as inferred from ontogenetic shifts by coral reef fishes. Gulf Caribb Res 14:43-59

Nagelkerken I, van der Velde G (2004) Relative importance of interlinked mangroves and seagrass beds as feeding habitats for juvenile reef fish on a Caribbean island. Mar Ecol Prog Ser 274:153-159

Nagelkerken I, Dorenbosch M, Verberk WCEP, Cocheret de la Morinière E, van der Velde G (2000a) Day-night shifts of fishes between shallow-water biotopes of a Caribbean bay, with emphasis on the nocturnal feeding of Haemuli- 
dae and Lutjanidae. Mar Ecol Prog Ser 194:55-64

Nagelkerken I, Dorenbosch M, Verberk WCEP, Cocheret de la Morinière E, van der Velde G (2000b) Importance of shallow-water biotopes of a Caribbean bay for juvenile coral reef fishes: patterns in biotope association, community structure and spatial distribution. Mar Ecol Prog Ser 202:175-192

Nagelkerken I, van der Velde G, Gorissen MW, Meijer GJ, van't Hof T, den Hartog C (2000c) Importance of mangroves, seagrass beds and the shallow coral reef as a nursery for important coral reef fishes, using a visual census technique. Estuar Coast Shelf Sci 51:31-44

Nagelkerken I, Kleijnen S, Klop T, van den Brand RACJ, Cocheret de la Morinière E, van der Velde G (2001) Dependence of Caribbean reef fishes on mangroves and seagrass beds as nursery habitats: a comparison of fish faunas between bays with and without mangroves/seagrass beds. Mar Ecol Prog Ser 214:225-235

Nagelkerken I, Roberts CM, van der Velde G, Dorenbosch M, van Riel MC, Cocheret de la Morinière E, Nienhuis PH (2002) How important are mangroves and seagrass beds for coral reef fish? The nursery hypothesis tested on an island scale. Mar Ecol Prog Ser 244:299-305

Nakamura Y, Sano M (2004) Overlaps in habitat use of fishes between a seagrass bed and adjacent coral and sand areas at Amitori Bay, Iriomote Island, Japan: importance of the seagrass bed as juvenile habitat. Fish Sci 70:788-803

Nanami A, Nishihira M (2001) Survival rates of juvenile coral reef fishes differ between patchy and continuous habitats. Bull Mar Sci 69:1209-1221

Nanami A, Nishihira M (2002) The structures and dynamics of fish communities in an Okinawan coral reef: effects of coral-based habitat structures at sites with rocky and sandy sea bottoms. Environ Biol Fish 63:353-372

Nanami A, Nishihira M (2003) Effects of habitat connectivity on the abundance and species richness of coral reef fishes: comparison of an experimental habitat established at a rocky reef flat and a sandy sea bottom. Environ Biol Fish 68:183-196

Odum HT (1983) Systems ecology: an introduction. Wiley, New York

Ogden JC, Buckman NS (1973) Movements, foraging groups, and diurnal migrations of the striped parrotfish Scarus croicensis Bloch (Scaridae). Ecology 54:589-596

Ogden JC, Ehrlich PR (1977) The behavior of heterotypic resting schools of juvenile grunts (Pomadasyidae). Mar Biol 42:273-280

Ogden JC, Zieman JC (1977) Ecological aspects of coral reef-seagrass bed contacts in the Caribbean. Proc 3rd Int Coral Reef Symp 1:377-382

Overholtzer KL, Motta PJ (1999) Comparative resource use by juvenile parrotfishes in the Florida Keys. Mar Ecol Prog Ser 177:177-187

Overholtzer-McLeod KL (2004) Variance in reef spatial structure masks density dependence in coral reef fish populations on natural versus artificial reefs. Mar Ecol Prog Ser 276:269-280

Overholtzer-McLeod KL (2005) Post-settlement emigration affects mortality estimates for two Bahamian wrasses. Coral Reefs 24:283-291

Parrish JD (1989) Fish communities of interacting shallowwater habitats in tropical oceanic regions. Mar Ecol Prog Ser 58:143-160

Platt JR (1964) Strong inference. Science 146:347-353

Ray M, Stoner AW (1995) Growth, survivorship, and habitat choice in a newly settled seagrass gastropod, Strombus gigas. Mar Ecol Prog Ser 123:83-94
Risk A (1997) Effects of habitat on the settlement and postsettlement success of the ocean surgeonfish Acanthurus bahianus. Mar Ecol Prog Ser 161:51-59

Robbins BD, Bell SS (1994) Seagrass landscapes: a terrestrial approach to the marine subtidal. Trends Ecol Evol 9: 301-304

Robertson DR (1989) The surgeonfish Acanthurus lineatus grows hedgers of macroalgae. Coral Reefs 8:8

Robertson DR (1991) Increases in surgeonfish populations after mass mortality of the sea urchin Diadema antillarum in Panama indicate food limitation. Mar Biol 111:437-444

Robertson DR, Kaufman K (1998) Assessing early recruitment dynamics and its demographic consequences among tropical reef fishes: accommodating variation in recruitment seasonality and longevity. Aust J Ecol 23:226-233

Rodriguez RW, Webb RMT, Bush DM (1994) Another look at the impact of Hurricane Hugo on the shelf and coastal resources of Puerto Rico, USA. J Coast Res 10:278-296

Rooker JR, Dennis GD (1991) Diel, lunar and seasonal changes in a mangrove fish assemblage off southwestern Puerto Rico. Bull Mar Sci 49:684-698

Rozas LP, Minello TJ (1998) Nekton use of salt marsh, seagrass, and nonvegetated habitats in a south Texas (USA) estuary. Bull Mar Sci 63:481-501

Sale PF, Cowen RK, Danilowicz BS, Jones GP and 7 others (2005) Critical science gaps impede use of no-take fishery reserves. Trends Ecol Evol 20:74-80

Salvanes AGV, Giske J, Nordeide JT (1994) Life history approach to habitat shifts for coastal cod, Gadus morhua L. Aquacult Fish Manag 25:215-218.

Sancho G, Ma D, Lobel PS (1997) Behavioral observations of an upcurrent reef colonization event by larval surgeonfish Ctenochaetus strigosus (Acanthuridae). Mar Ecol Prog Ser 153:311-315

Sandt VJ, Stoner AW (1993) Ontogenetic shift in habitat by early juvenile queen conch, Strombus gigas: patterns and potential mechanisms Fish Bull (Wash DC) 91:516-525

Sedberry GR, Carter J (1993) The fish community of a shallow tropical lagoon in Belize, Central America. Estuaries 16: 198-215

Serafy JE, Faunce CH, Lorenz JJ (2003) Mangrove shoreline fishes of Biscayne Bay, Florida. Bull Mar Sci 72:161-180

Sheaves M (1995) Large lutjanid and serranid fishes in tropical estuaries: are they adults or juveniles? Mar Ecol Prog Ser 129:31-40

Sheridan P, Hays C (2003) Are mangroves nursery habitat for transient fishes and decapods? Wetlands 23:449-458

Shulman MJ (1984) Resource limitation and recruitment patterns in a coral reef fish assemblage. J Exp Mar Biol Ecol 74:85-109

Shulman MJ (1985) Recruitment of coral reef fishes: effects of distribution of predators and shelter. Ecology 66: 1056-1066

Shulman MJ, Ogden JC (1987) What controls tropical reef fish populations: recruitment or benthic mortality? An example in the Caribbean reef fish Haemulon flavolineatum. Mar Ecol Prog Ser 39:233-242

Simberloff D (1983) Competition theory, hypothesis-testing, and other community ecology buzz-words. Am Nat 122: 626-635

Sobel JA, Dahlgren CP (2004) Marine reserves: a guide to science, design, and use. Island Press, Washington, DC

Sogard SM (1997) Size-selective mortality in the juvenile stage of teleost fishes: a review. Bull Mar Sci 60:1129-1157

Sponaugle S, Cowen RK (1997) Early life history traits and recruitment patterns of Caribbean wrasses (Labridae). Ecol Monogr 677:177-202 
St. John J (1999) Ontogenetic changes in the diet of the coral reef grouper Plectropomus leopardus (Serranidae): patterns in taxa, size and habitat of prey. Mar Ecol Prog Ser 180:233-246

Stoner AW (2003) What constitutes essential nursery habitat for a marine species? A case study of habitat form and function for queen conch. Mar Ecol Prog Ser 257:275-289

Stoner AW, Ray M (1993) Aggregation dynamics in juvenile queen conch population structure, mortality, growth and migration. Mar Biol 116:571-582

Stoner AW, Sandt VJ (1991) Experimental analysis of habitat quality for juvenile queen conch in seagrass meadows. Fish Bull (Wash DC) 89:693-700

Strong DR, Simberloff JD, Abele JG, Thistle AB (1984) Ecological communities: conceptual issues and the evidence. Princeton University Press, Princeton, NJ

Sweatman H, Robertson DR (1994) Grazing halos and predation on juvenile Caribbean surgeonfishes. Mar Ecol Prog Ser 111:1-6

Szedlmayer ST, Able KW (1993) Ultrasonic telemetry of age-0 summer flounder, Paralichthys dentatus, movements in a southern New Jersey estuary. Copeia:728-736

Thayer GW, Colby DR, Hettler WF (1987) Utilization of the red mangrove prop root habitat by fishes in south Florida. Mar Ecol Prog Ser 35:25-38

Thollot P (1993) Importance of mangroves for Pacific reef fish species, myth or reality? Proc 7th Int Coral Reef Symp 2: 934-941

Thollot P, Kulbicki M (1989) Overlap between the fish fauna inventories of coral reefs, soft bottoms and mangroves in Saint-Vincent Bay (New Caledonia). Proc 6th Int Coral Reef Symp 2:613-618

Thorrold SR, Jones CM, Swart PK, Targett TE (1998) Accurate

Editorial responsibility: Otto Kinne (Editor-in-Chief), Oldendorf/Luhe, Germany classification of juvenile weakfish Cynoscion regalis to estuarine nursery habitats based on chemical signatures in otoliths. Mar Ecol Prog Ser 173:253-265

Thorrold SR, Jones GP, Hellberg ME, Burton RS, Swearer SE, Neigel JE, Morgan SG, Warner RR (2002) Quantifying larval retention and connectivity in marine populations with artificial and natural markers. Bull Mar Sci 70 (Suppl):291-308

Tolimieri N (1995) Effects of microhabitat characteristics on the settlement and recruitment of a coral reef fish at two spatial scales. Oecologia 102:52-63

Tolimieri N (1998) Effects of substrata, resident conspecifics and damselfish on the settlement and recruitment of the stoplight parrotfish, Sparisoma viride. Environ Biol Fish 53:393-404

Turner SJ, Thrush SF, Hewitt JE, Cummings VJ, Funnell G (1999) Fishing impacts and the degradation or loss of habitat structure. Fish Manag Ecol 6:401-420

Utne ACW, Aksnes DL (1994) An experimental study on the influence of feeding versus predation risk in the habitat choice of juvenile and adult two-spotted goby Gobiusculus flavescens (Fabricius). J Exp Mar Biol Ecol 179:69-79

Werner EE, Gilliam JF (1984) The ontogenetic niche and species interactions in size-structured populations. Annu Rev Ecol Syst 15:393-425

Wetherbee BM, Holland KN, Meyer CG, Lowe CG (2004) Use of Kaneohe Bay, Hawaii by the giant trevally, Caranx ignobilis. Fish Res 67:253-263

Yamashita Y, Otake T, Yamada H (2002) Relative contributions from exposed inshore and estuarine nursery grounds to the recruitment of stone flounder, Platichthys bicoloratus, estimated using otolith $\mathrm{Sr}: \mathrm{Ca}$ ratios. Fish Oceanogr 9: $316-32$

Submitted: June 9, 2005; Accepted: December 19, 2005 Proofs received from author(s): July 19, 2006 